\title{
Persistence Of Performance Using The Four-Factor Pricing Model: Evidence From Dow Jones Islamic Index
}

\author{
Abdelbari El Khamlichi, CRCGM, Université d'Auvergne, France \\ Mohamed Arouri, EDHEC Business School, France \\ Frédéric Teulon, IPAG Business School, France
}

\begin{abstract}
Despite the increasing attention to ethical investments, the empirical studies on Islamic indices are scarce. The main goal of this article is to investigate whether Dow Jones Islamic Index 100 Titans (DJI100) delivers persistent performance. Using the Carhart (1997) four-factor model, we consider all historical data available from the launching of the index by Dow Jones on September 1999 to March 2011. We study all the firms included in the index and we construct the risk factors (Market premium, size, Book-to-Market, momentum). Our findings show positive performance for momentum strategy and support the idea that ethical investments could under-perform and thus investors accept to pay for their ethics.
\end{abstract}

Keywords: Persistence; Islamic Indices; Performance; Four-Factor Model

\section{INTRODUCTION}

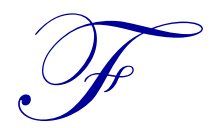

inancial literature distinguishes between the return of past winners and past losers. Actually, we should observe either performance persistence or performance reversal. If past losers (winners) become future winners (losers), this situation could be described as an overreaction toward new information (De Bondt \& Thaler, 1985). Otherwise, if past winners continue to over perform past losers, the performance is deemed to be persistent (Jegadeesh \& Titman, 1993).

In order to assess the performance of managed portfolios by predicting risks and returns, various models exist. The CAPM of Sharpe (1964) and Lintner (1965) suggests to compare return and risk with market portfolio. The Fama and French (1993) three-factor Model was suggested to capture much of the variation of average return. This model is based on three factors: The first one is the market excess return or the market premium (Rm-Rf). The second factor is the size premium which measures the difference between the return of small capitalizations and big capitalizations (Small minus Big or SMB). The third factor is the book-to-market premium computed by taking the difference between the return of value and growth portfolios (High minus Low or HML). The Carhart (1997) model extends the Fama and French (1993) model by adding to it an effect documented by Jegadeesh and Titman (1993). The added factor is momentum which measures difference between past winners and past losers and thus the persistence of performance (Up minus Down or UMD).

Ethical investment performance is well documented in the finance literature, but neither its over performance nor its underperformance could win the searcher's unanimous support. Our article contributes to current debates; we try to provide additional evidence from Islamic indices as a part of faith-based or morallyresponsible investment. Thus, we investigate whether Dow Jones Islamic Index 100 Titans (DJI100) delivers persistent performance, we use Carhart (1997) four-factor pricing model. We construct factors using both Fama and French (1993) and Carhart (1997) methodologies. We assess the persistence performance of the Islamic Index, by applying the four-factor pricing model to the firms included in DJI100. Next, we extend the study to highlight the turn-of-the-year effect (January effect) since the previous works find seasonality in momentum profits. Finally we 
study the index persistence of performance over the business cycle, by distinguishing recession and expansion periods.

The remainder of this paper is organized as follows: In Section 2, we introduce briefly the basic framework of the Islamic finance industry and Islamic indices' universe. In Section 3 we present our data and methodology. Section 4 discusses the empirical results and Section 5 concludes the article.

\section{PRESENTATION OF ISLAMIC FINANCE AND INDICES} following:

Islamic finance is based on a set of principles referred to as Shariah (Islamic Law). The 5 principles are the

- $\quad$ The profit and loss sharing

- The prohibition of interest

- $\quad$ The asset-backing

- The prohibition of excessive uncertainty

- The prohibition of some sectors (alcohol, pork-related products, conventional banks and insurance, gambling...)

Another principle is zakat which is a form of charity paid on personal wealth which exceed the "Nisab" and held for one complete year. The rate of zakat on most forms of monetary wealth and earned income is $2.5 \%$. For Islamic financial institutions and mutual funds, the calculation is usually performed by supervisory Shariah board.

By applying these principles, the Islamic financial system was established to take into consideration besides religious aspects - moral, ethical, and social dimensions. In recent years, Islamic banking and finance has been recognized as a rapidly-growing part of the financial sector (Čihák \& Hesse, 2010). This was a result of the increasing attention to Islamic investments driven by the recent innovations in Islamic finance. The later covers for example the banking system, the mutual funds industry, derivatives, stock market, insurance, and reinsurance industry.

Another aspect of this innovation was the Shariah compliant indices which are equity benchmark indices designed to track the performance of publicly traded Shariah-compliant companies. Indeed, Islamic indices are considered as part of morally-responsible investments (Ghoul \& Karam, 2007) and their principle is similar to that of social indices in terms of screening (Novethic, 2009), both of them have supervisory boards which provide advice on eligibility of companies, but the main difference between them is that the referent is religious for Islamic indices and compliance is guaranteed by Shariah boards.

Chronologically, Islamic indices were launched for the first time in the late nineties, the beginning was on April 1998 with the index DMI 150 (Dar al Mal al-Islami) launched jointly by two private banks (Faisal Finance and Bank Vontobel) in order to measure the performance of the 150 largest global publicly traded companies. Another index was created on November of the same year; it was SAMI (Socially Aware Muslim Index) which measured the performance of 500 Shariah compliant companies.

After this beginning, several financial markets had launched their own Islamic indices as a new alternative for the investors seeking for investment opportunities without compromising their beliefs. That way Dow Jones created the Dow Jones Islamic Market Index (DJIMI) on February 1999 and FTSE Group launched Global Islamic Index Series (GIIS) at London Stock Exchange on October 1999. The index provider, Standard and Poor's, created the Global Benchmark Shariah indices on December 2006 and MSCI Barra launched its global family of Islamic indices on March 2007. On February 2011, Stoxx limited introduced the first set of Shariah compliant indices for Europe and Euro zone; these indices measure the performance of Shariah compliant companies selected from the universe of Stoxx Europe 600 index (see Appendix 1 for more details).

In addition to the previous indices which had an internationally geographical coverage, some financial places had introduced their own Islamic indices with a local focus; that's the case for the stock exchanges of Malaysia, India, Pakistan, Saudi Arabia, Taiwan, Bahrain, Turkey, Egypt, etc. 
All Islamic indices have a common feature, which is the selection process, they use screening as a prevalent method for selecting their constituents. The benchmarks from which Islamic indices are selected are well-recognized conventional indices. The independent Shariah boards carry out the screening process regarding the activity sector of firms and their financial ratios (Appendix 2).

\subsection{Previous Works}

The persistence of the performance of the US stock market has received a high level of academic scrutiny, the majority of research focused on the American mutual funds (Carhart, 1997). Nevertheless, the persistence of performance using the four-factor models has been studied for the Canadian stock market (L'Her et al., 2004), the Australian market (Humphrey \& O'Brien, 2010), the British market (Ferruz et al., 2010), and Lilty and Gouzerh (2007) who scrutinized the performance persistence of an international portfolio.

The purpose of these studies is to determine whether the selection of assets with ethical screening could lead to over performance. According to Schröder (2007) and Bauer et al. (2007), searchers in general observe no evidence of significant differences in risk-adjusted returns between ethical and conventional investments. This conclusion is confirmed recently by Le Sourd (2011) which finds that the majority of differences are not significant and the only few significant alpha values are negatives (underperformance) even if the study used a constructed efficient ethical index.

Early studies on Islamic financial markets discussed the feasibility of an Islamic stock market (Elgari, 1993) and its particularities in terms of practices and regulation (Alhabshi, 1994). Whereas Islamic mutual funds have been the subject of many academic researches (Annuar et al., 1997; Ismail et Shakrani, 2003; Elfakhani et al., 2005; Abdullah et al., 2007; Saad et al., 2010), Islamic indices have not received the same level of scrutiny. This situation can be explained by the short histories of Islamic indices and by some methodological difficulties due to differences in size and industry-weighting which complicated performance comparisons against benchmark indices (Fowler \& Hope, 2007).

However, Schröder (2007) argues that the study of indices has advantages since various issues don't have to be considered. Thus by analyzing the performance of indices the searcher avoids methodological problems related to transaction costs, the timing activities, the skill of the fund management, and the changes in investment policy.

To the best of our knowledge, the persistence of the performance of Islamic indices using the four factor model was studied only in three papers (Girard \& Hassan, 2005, 2008; Abul Hassan et al., 2005). Girard and Hassan (2005) find that there is no significant difference between Islamic and conventional indices. Their sample of Dow Jones Islamic indices outperform the conventional counterparts from January $1996^{1}$ to November 2000 and underperform from December 2000 to November 2005. Indeed, after controlling for market risk, size, book-tomarket, and momentum, the difference in return between Islamic and conventional returns remain negligible (no significant alpha).

The authors confirm these findings in their subsequent study (Girard \& Hassan, 2008) in which they analyzed the FTSE Shariah index from January 1999 to December 2006 and they found no convincing performance differences. By studying the size, book-to-market, and momentum effects, they found that Islamic indices are growth and small-cap oriented and conventional indices are relatively more value and mid-cap focused. Applying the same four-factor model, Abul Hassan et al. (2005) used the monthly data of Dow Jones indices from January 1996 to December 2003; their findings indicate that the Islamic ethical screens do not necessarily have an adverse impact on investment performance.

There are two main differences between these three previous works and our current study. First, the exclusion of non-ethical stocks (sin stocks) from Islamic indices leads to exclude "recession-proof" stocks (Hong \& Kacperczyk, 2009). For this reason, we study the persistence of performance over the business cycle by suggesting a

\footnotetext{
${ }^{1}$ The authors used back-tested data, since the studied Islamic indices have been introduced on February 1999, but data are available back to December 31, 1995.
} 
model in which we distinguish between expansion and recession periods. Second, we study the seasonality of the momentum profits for the 100 firms included in the Dow Jones Islamic Index Titans 100.

\section{DATA AND METHODOLOGY}

\subsection{Data}

Our study covers the period from September 1999 to March 2011 and the required monthly data were retrieved either from Datastream or Factset databases. With regard to Islamic indices, we consider the Dow Jones Islamic Index Titans 100 (DJI100), the benchmark is a conventional large index from the Dow Jones family: Dow Jones Global World Index (W1DOW).

Factset database is used in order to collect data on accounting figures of firms included in the Dow Jones Islamic Index. Thus we construct portfolios based on the size (SMB), the book-to-market (HML), and the momentum (UMD). The methodology of construction of these factors is described below. As a proxy for the riskfree rate we use the US Treasury Bill (3 month), data are available in Factset database. Also we choose not to include back-tested data, since even if data are available back to December 31, 1995, the Dow Jones Islamic Index Titans 100 hasn't been really launched until September 1999.

\subsection{Methodology}

By using the four-factor pricing model, we suggest to study the performance persistence of firms composing the Dow Jones Islamic Market Titans 100 Index.

The model can be written as:

$$
\left(R_{t}-R_{f t}\right)=\alpha+\beta\left(R_{m t}-R_{f t}\right)+\beta_{s} S M B_{t}+\beta_{h} H M L_{t}+\beta_{u} U M D_{t}+\varepsilon_{t}
$$

Where:

- $\quad\left(R_{m t}-R_{f t}\right)$ is the market return in excess of the risk-free rate, or the market premium.

- $\quad S M B$ (Small Minus Big) or the size factor is computed by taking the difference between the return of small capitalization (S) and big capitalization (B) portfolios.

- $\quad H M L$ (High Minus Low) or the value factor is computed by taking the difference between the return of High book-to-market $(\mathrm{H})$ and the Low book-to-market (L) portfolios.

- $\quad U M D$ (Up Minus Down) or the momentum factor is computed each month by taking the difference between past winners (U) and past losers (D) over 12-month-return.

The factors SMB, HML, and UMD are estimated according to the methodology suggested by Fama and French (1993) and L'Her et al. (2004). SMB and HML are calculated annually with combinations of equally weighted portfolios composed by ranked stocks in ascending order of size and book to market. The momentum factor (UMD) is calculated monthly with intersection of two portfolios formed on size and three portfolios formed on prior return. In line with Carhart (1997), we equally weighted firm returns to form the portfolios and we consider the formation period from month -12 to month -1 and holding period from month 1 to month 12 . 
For the three factors, the used breakpoints are the following:

Table 1: The Breakpoints used for the Constitution of Portfolios

\begin{tabular}{|l|c|c|c|}
\hline Size & \multicolumn{2}{|c|}{$\begin{array}{c}50 \% \mathrm{~S} \\
\text { (5 top deciles: lower than the median) }\end{array}$} & $\begin{array}{c}\text { (5 bottom deciles: higher than the median) } \\
\text { Book to Market }\end{array}$ \\
$\begin{array}{l}30 \% \mathrm{H} \\
\text { (3 bottom deciles) }\end{array}$ & $\begin{array}{c}40 \% \mathrm{M} \\
\text { (4 medium deciles) }\end{array}$ & $\begin{array}{c}30 \% \mathrm{~L} \\
\text { (3 top deciles) }\end{array}$ \\
\hline Momentum & $\begin{array}{c}30 \% \mathrm{U} \\
\text { (3 bottom deciles) }\end{array}$ & - & $\begin{array}{c}30 \% \mathrm{D} \\
\text { (3 top deciles) }\end{array}$ \\
\hline
\end{tabular}

With this combination we obtain the following portfolios:

Table 2: The Combination of Size, Book-to-Market and Momentum Effect

\begin{tabular}{|l|c|c|c|c|c|}
\cline { 2 - 6 } \multicolumn{1}{c|}{} & High B/M & Median B/M & Low B/M & Winners $(\boldsymbol{U}$ ) & Losers $($ Down) \\
\hline Big caps & $\mathrm{BH}_{\text {(annually) }}$ & $\mathrm{BM}_{(\text {annually) }}$ & $\mathrm{BL}_{(\text {annually })}$ & $\mathrm{BU}_{\text {(monthly) }}$ & $\mathrm{BD}_{(\text {monthly })}$ \\
\hline Small caps & $\mathrm{SH}_{\text {(annually) }}$ & $\mathrm{SM}_{\text {(annually) }}$ & $\mathrm{SL}_{(\text {annually) }}$ & $\mathrm{SU}_{\text {(monthly) }}$ & $\mathrm{SD}_{(\text {monthly) }}$ \\
\hline
\end{tabular}

Then, the 3 factors are calculated as follows:

$$
\begin{aligned}
& \text { - } \quad S M B=\frac{(S L-B L)+(S M-B M)+(S H-B H)}{3} \\
& \text { - } \quad H M L=\frac{(B H-S H)+(B L-S L)}{2} \\
& \text { - } \quad U M D=\frac{(S U-S D)+(B U-B D)}{2}
\end{aligned}
$$

After calculating the factors, we will compare SMB and HML with those found by Fama and French (1996) for the US market in terms of return and risk, and the momentum factor (UMD) will be compared with that of Jegadeesh and Titman (2001) as calculated and annualized by L'Her et al. (2004).

We also investigate momentum seasonality documented by Jegadeesh and Titman (1993) and confirmed in a subsequent research (Jegadeesh \& Titman, 2001) considering that the winners outperform losers in all months except January where losers outperform the winners. In addition, we study the sensitivity of the stocks composing the Dow Jones Islamic Market Titans100 Index to the economic conditions; it comes to analyze their performance over the business cycle. For that, we use the methodology of Salaber (2012) by applying the Carhart model with a dummy variable which accounts for recession. The periods of expansion and recession correspond to those defined by The National Bureau of Economic Research (NBER).

Let D' denote the dummy variable, which equals 1 in a recession period and 0 otherwise. Thus, the fourfactor model becomes:

$$
\begin{aligned}
& \left(R_{t}-R_{f t}\right)=\alpha+\beta\left(R_{m t}-R_{f t}\right)+\beta_{s} S M B_{t}+\beta_{h} H M L_{t}+\beta_{u} U M D_{t} \\
& +\alpha^{\prime} D^{\prime}+\beta^{\prime} D^{\prime}\left(R_{m t}-R_{f t}\right)+\beta^{\prime}{ }_{s} D^{\prime} S M B_{t}+\beta_{h} D^{\prime} H M L_{t}+\beta_{u} D^{\prime} U M D_{t}+\varepsilon_{t}
\end{aligned}
$$

Then we estimate the parameters of this equation in autoregressive conditional heteroskedasticity or ARCH framework as introduced by Engle (1982); this process allows the conditional variance $\sigma_{t}^{2}$ to change over time as a function of past errors leaving the unconditional variance constant.

\section{EMPIRICAL RESULTS}

Firstly, we present summary statistics of the four factors and correlation between them. Then we present the results of the regressions on these factors and the behaviour over the business cycle. 
Table 3: Summary Statistics and Correlations between the Four Factors

$\mathrm{R}_{\mathrm{f}}$ stands for the risk-free rate (US T-bill), SMB is the size factor, HML is the book-to market factor calculated each year, UMD is the momentum factor calculated monthly for the firms included in the Dow Jones Islamic Index titans 100. Data are based on monthly returns from September 1999 to March 2011 ( $\mathrm{N}=139)$. * Indicates significance at $1 \%$ level

\begin{tabular}{|c|c|c|c|c|}
\hline \multicolumn{5}{|c|}{ (3.1) Summary Statistics } \\
\hline & RM_RF & SMB & HML & UMD \\
\hline Mean & -0.022141 & 0.006234 & 0.002100 & $0.045637 *$ \\
\hline Std. Dev. & 0.058494 & 0.037416 & 0.052662 & 0.054691 \\
\hline t-mean & -1.288260 & 0.567117 & 0.135733 & 2.839975 \\
\hline \multicolumn{5}{|c|}{ (3.2) Correlations } \\
\hline & RM_RF & SMB & HML & UMD \\
\hline RM_RF & 1 & & & \\
\hline SMB & 0.090318 & 1 & & \\
\hline HML & 0.153757 & -0.038897 & 1 & \\
\hline UMD & -0.059848 & 0.067898 & -0.121794 & 1 \\
\hline
\end{tabular}

Over the September 1999 - March 2011 period, the summary statistics on the four factors presented on Table 3 (3.1) show that the average market premium is lower than the other factor's premiums and the UMD portfolio has the highest premiums. This means that momentum strategy has positive performance over the September 1999 - March 2011 period. Also SMB premium is positive, meaning that small stocks have performed better than big ones, the difference of $0.62 \%$ per month (7.44\% per year) is higher but less significant than $4.92 \%$ reported by Fama and French (1996). Value stocks have higher returns than growth ones, the difference of $0.21 \%$ per month (2.52\% per year) is lower and less significant than 6.33\% reported by Fama and French (1996). When we compare the average standard deviation, we find that the volatility of SMB premium (3.74\% per month or $12.96 \%$ per year) is much lower than the market premium (20.23\%) and the 15.44\% reported by Fama and French (1996). However HML premium with a standard deviation of $5.26 \%$ per month $(18.24 \%$ per year) is more risky than that of Fama and French (13.11\%) as calculated and annualized by L'Her et al. (2004).

We also note that the correlations between the four factors are very low as shown in Table 3 (3.2). This is not a surprising result since it remains consistent with the way we construct the four factors. Indeed, we use the dual sort procedure which neutralizes the size effect when we have calculated book-to-market factor and the momentum factor each month for the firms included in the DJI100 index as we described in the methodology. This low crosscorrelation between the four factors was revealed by Carhart (1997) and confirmed by other searchers, notably by L'Her et al. (2004).

In order to highlight the seasonality in returns, we present the summary statistics of the four factors on monthly basis:

Table 4: The Mean and the Standard Deviation of the Four Factor Returns per Month

This table presents the Mean and the standard deviation of the returns of four-factors of Carhart model from September 1999 to March $2011(\mathrm{~N}=139) . \mathrm{R}_{\mathrm{m}}-\mathrm{R}_{\mathrm{f}}$ stands for the market premium, SMB is the size factor, HML is the Book-to-Market factor, UMD is the momentum factor. SEM is the Standard Error of the Mean calculated by dividing standard deviation by the square root of the sample size $(\mathrm{N}) .{ }^{*}$ Indicates significance at $1 \%$ level

\begin{tabular}{|c|c|c|c|c|c|c|c|c|c|c|c|c|}
\hline & \multicolumn{4}{|c|}{ Mean } & \multicolumn{4}{|c|}{ Standard Deviation } & \multicolumn{4}{|c|}{ SEM } \\
\hline & $\boldsymbol{R}_{m}-\boldsymbol{R}_{f}$ & $S M B$ & $H M L$ & $U M D$ & $\boldsymbol{R}_{m}-\boldsymbol{R}_{f}$ & $S M B$ & $H M L$ & $U M D$ & $\boldsymbol{R}_{m}-\boldsymbol{R}_{f}$ & $S M B$ & $H M L$ & $U M D$ \\
\hline January & $-0.0427^{*}$ & 0.0112 & -0.0185 & 0.0252 & 0.1535 & 0.0803 & 0.1223 & 0.2361 & 0.0130 & 0.0068 & 0.0104 & 0.0200 \\
\hline February & $-0.0382^{*}$ & -0.0029 & 0.0107 & 0.0397 & 0.1916 & 0.1851 & 0.2730 & 0.3099 & 0.0163 & 0.0157 & 0.0232 & 0.0263 \\
\hline March & -0.0046 & 0.0032 & 0.0160 & $0.0269^{*}$ & 0.2251 & 0.0902 & 0.1471 & 0.1066 & 0.0191 & 0.0077 & 0.0125 & 0.0090 \\
\hline April & -0.0002 & -0.0042 & 0.0012 & $0.0297^{*}$ & 0.1926 & 0.1127 & 0.2581 & 0.1489 & 0.0163 & 0.0096 & 0.0219 & 0.0126 \\
\hline May & -0.0204 & 0.0112 & 0.0174 & 0.0171 & 0.2697 & 0.2164 & 0.2309 & 0.2939 & 0.0229 & 0.0184 & 0.0196 & 0.0249 \\
\hline June & $-0.0410^{*}$ & 0.0147 & -0.0234 & $0.0651^{*}$ & 0.1940 & 0.1346 & 0.1916 & 0.2732 & 0.0165 & 0.0114 & 0.0162 & 0.0232 \\
\hline July & -0.0292 & 0.0232 & 0.0000 & $0.0581^{*}$ & 0.2415 & 0.2166 & 0.1744 & 0.1273 & 0.0205 & 0.0184 & 0.0148 & 0.0108 \\
\hline August & -0.0178 & 0.0159 & 0.0138 & $0.0500^{*}$ & 0.8661 & 0.1517 & 0.1255 & 0.1271 & 0.0735 & 0.0129 & 0.0106 & 0.0108 \\
\hline September & -0.0392 & 0.0044 & -0.0060 & $0.0595^{*}$ & 0.2829 & 0.0866 & 0.1795 & 0.1542 & 0.0240 & 0.0073 & 0.0152 & 0.0131 \\
\hline October & -0.0242 & -0.0127 & 0.0043 & 0.0614 & 0.2475 & 0.1223 & 0.1627 & 0.1882 & 0.0210 & 0.0104 & 0.0138 & 0.0160 \\
\hline November & -0.0177 & 0.0166 & -0.0111 & $0.0535^{*}$ & 0.2281 & 0.1391 & 0.1326 & 0.1041 & 0.0193 & 0.0118 & 0.0112 & 0.0088 \\
\hline December & 0.0080 & -0.0051 & $0.0310^{*}$ & $0.0610^{*}$ & 0.2039 & 0.1126 & 0.1588 & 0.1447 & 0.0173 & 0.0095 & 0.0135 & 0.0123 \\
\hline
\end{tabular}


Table 4 shows results in line with Jegadeesh and Titman (2001), we find that the winners outperform losers in all month as momentum factor is positive. However, the difference is significant only for 8 months but not for the other months. So we don't find that January is an exceptional month in which losers significantly outperform the winners as documented in the literature by Jegadeesh and Titman $(1993 ; 2001)$.

Table 5: Results from Regression on Carhart Four Factor Model

\begin{tabular}{|c|c|c|c|c|}
\hline$\alpha$ & $\beta$ & $\beta_{s}$ & $\beta_{h}$ & $\beta_{u}$ \\
\hline $\begin{array}{l}\mathbf{- 0 . 0 1 3 4} * * * \\
(0.0032)\end{array}$ & $\begin{array}{c}\mathbf{0 . 3 0 4 9} * * * * \\
(0.0000)\end{array}$ & $\begin{array}{c}0.1304 \\
(0.2294)\end{array}$ & $\begin{array}{c}-0.0050 \\
(0.9404)\end{array}$ & $\begin{array}{c}-0.00828 \\
(0.1384)\end{array}$ \\
\hline
\end{tabular}

Table 5 shows the estimation in ARCH (2) framework of the Carhart four-factor model. The alpha value is negative and significant at $1 \%$ level, which means that the selection of assets with Islamic screening produces a negative performance due to the lack of diversification, which is consistent with the portfolio theory (Barnett \& Salomon, 2006). Also, the coefficient of market risk premium is positive and significant which means that historical higher rate is associated with risky investments.

We extend the analysis to study the persistence of the performance over the economic cycle, the goal is to see whether the behaviour of the firms of our sample changes in recession or expansion periods according to the NBER business cycle reference dates.

Table 6: Results from Regression on Carhart Four-Factor Model Including Dummy Variable for Recession DJI100 stands for Dow Jones Islamic 100 titans index, W1DOW represents Dow Jones Global index. We test the following equation by allowing for ARCH (2) framework:

$\left(R_{t}-R_{f t}\right)=\alpha+\beta\left(R_{m t}-R_{f t}\right)+\beta_{s} S M B_{t}+\beta_{h} H M L_{t}+\beta_{u} U M D_{t}+\alpha^{\prime} D_{t}^{\prime}+\beta^{\prime} D_{t}^{\prime}\left(R_{m t}-R_{f t}\right)+\beta_{s}^{\prime} D_{t}^{\prime} S M B_{t}+\beta_{h} D_{t}^{\prime} H M L_{t}+\beta_{u} D_{t}^{\prime} U M D_{t}+\varepsilon_{t}$ $*, * *, * * *$ indicate significance respectively at the $10 \%, 5 \%$ and $1 \%$ confidence levels. $\mathrm{P}$ values are given in parentheses:

\begin{tabular}{|c|c|c|c|c|c|c|c|c|c|}
\hline \multicolumn{1}{|c|}{$\alpha$} & $\beta$ & $\beta_{s}$ & $\beta_{h}$ & $\beta_{u}$ & $\alpha^{\prime}$ & $\beta^{\prime}$ & $\beta_{s}{ }^{\prime}$ & $\beta_{h}{ }^{\prime}$ & $\beta_{u}{ }^{\prime}$ \\
\hline-0.009 & $\mathbf{0 . 3 9 1}^{* * * *}$ & 0.074 & 0.003 & 0.071 & $\mathbf{- 0 . 0 2 2}^{*}$ & $\mathbf{- 0 . 2 4 5}^{*}$ & 0.428 & -0.065 & -0.119 \\
$(0.103)$ & $(0.000)$ & $(0.552)$ & $(0.976)$ & $(0.240)$ & $(0.083)$ & $(0.096)$ & $(0.925)$ & $(0.715)$ & $(0.514)$ \\
\hline
\end{tabular}

Table 6 shows that by adding the dummy variable to take into account the recession, only $\beta$ remains significant and increase in absolute magnitude against the benchmark. The additional information comes from $\alpha^{\prime}$ and $\beta^{\prime}$ which are negative and significant at $10 \%$ level, it means that the market premium is higher in the recession period than in expansion period. These findings can be explained by the exclusion of some industries considered to be recession-proof, for example during bad times people don't reduce their consumption of alcoholic products, tobacco, gambling, etc. which remains in line with the findings of researches on sin stocks.

\section{CONCLUSION}

Using the four-factor model, we studied the performance of an Islamic index by constructing various portfolios from the component firms. Islamic indices as well as all ethical indices are a subset of well diversified indices, the screening process reduces the number of included firms and causes a lack of diversification.

In order to learn more about the performance persistence of ethical investments we construct portfolios based on the size (SMB), the book-to-market (HML), and the momentum (UMD) as documented in the finance literature. Then we examined the mean and the risk of constructed portfolios from 1999 to 2011. Our results show very low correlations between factors as well as positive performance for momentum strategy over the period. But we found no seasonality in momentum profits.

Then, we used the four-factor regression analysis; we found no evidence of persistence across the performance of the Islamic index. Thus, in comparison with the benchmark, this index produces an average negative 
alpha from 1999 to 2011 including the recession period which means that ethical screening criteria could not produce a positive performance, after neutralizing the size and the style differences. However, it seems that this under-performance does not influence ethical investors which seem to be more concerned with ethical issues than financial performance, in many cases they accept to pay a price for their ethics.

\section{AUTHOR INFORMATION}

Abdelbari El Khamlichi, CRCGM, Université d'Auvergne, France

Mohamed Arouri, EDHEC Business School, France

Frédéric Teulon, IPAG Business School, Department of Finance, Paris, France. E-mail: f.teulon@ipag.fr (Corresponding author)

\section{REFERENCES}

1. Abdullah, F., Hassan, T., \& Mohamad, S. (2007). Investigation of performance of Malaysian Islamic unit trust funds. Managerial Finance, 33(2), 142-153.

2. Abul, H., Antonios, A., \& Krishna, P. D. (2005). Impact of ethical screening on investment performance: The case of Dow Jones Islamic Index. Islamic Economic Studies, 12-13(1-2), 69-97.

3. Alhabshi, S. (1994). Development of capital market under Islamic principles. Conference on Managing and Implementing Interest-Free Banking. Centre For Management Technology, Kuala Lumpur, Malaysia: January 25-26.

4. Annuar, M. N., Shamsher, M., \& Ngu, M. H. (1997). Selectivity and timing: Evidence from the performance of Malaysian unit trusts. Pertanika Journal of Social Science and Humanities, 5(1), 45-57.

5. Barnett, M. L., \& Salomon, R. M. (2006). Beyond dichotomy: The curvilinear relationship between social responsibility and financial performance. Strategic Management Journal, 27(11), 1101-1122.

6. Bauer, R., Derwall, J., \& Otten, R. (2007). The ethical mutual fund performance debate: New evidence from Canada. Journal of Business Ethics, 70(2), 111-124.

7. De Bondt, W., \& Thaler, R. (1985). Does the stock market overreact? Journal of Finance, 40(3), 793-805.

8. Carhart, M. M. (1997). On persistence in mutual fund performance. Journal of Finance, 52(1), 57-82.

9. $\quad$ Čihák, M., \& Hesse, H. (2010). Islamic banks and financial stability: An empirical analysis. Journal of Financial Services Research, 38(2-3), 95-113.

10. Elfakhani, S., Hassan, M. K., \& Sidani, Y. (2005). Comparative performance of Islamic versus secular mutual funds. The Economic Research Forum Conference in Cairo, Egypt, December 19-21.

11. Elgari, M. A. (1993). Towards an Islamic stock market. Islamic Economic Studies, 1(1), 1-20.

12. Fama, E. F., \& French, K. R. (1993). Common risk factors in the returns on stocks and bonds. Journal of Financial Economics, 33(1), 3-56.

13. (1998). Value versus growth: the international evidence. Journal of Finance, 1975-1999.

14. Ferruz, L., Munoz, F., \& Vargas, M. (2010). Stock picking, market timing and style differences between socially responsible and conventional pension funds: evidence from the United Kingdom. Business Ethics: A European Review, 19(4), 408-422.

15. Fowler, S. J., \& Hope, C. (2007). A critical review of sustainable business indices and their impact. Journal of Business Ethics, 76(3), 243-252.

16. Ghoul, W., \& Karam, P. (2007). MRI and SRI mutual funds: A comparison of Christian, Islamic (morally responsible investing), and socially responsible investing (SRI) mutual funds. Journal of Investing, 16(2), 96.

17. Girard, E., \& Hassan, M. K. (2005). Faith-based ethical investing: The case of Dow Jones Islamic Indexes. 2006 FMA Annual Meeting, Chicago. Retrieved from http://www.fma.org

18. (2008). Is there a cost to faith-based investing: Evidence from FTSE Islamic Indices. The Journal of Investing, 17(4), 112-121.

19. Hong, H., \& Kacperczyk, M. (2009). The price of sin: The effects of social norms on markets. Journal of Financial Economics, 93(1), 15-36. 
20. Humphrey, J., \& O’Brien, M. A. (2010). Persistence and the four-factor model in the Australian funds market: A note. Accounting \& Finance, 50(1), 103-119.

21. Ismail, A. G., \& Shakrani, M. S. (2003). The conditional CAPM and cross-sectional evidence of return and beta for Islamic unit trusts in Malaysia. IIUM Journal of Economics and Management, 11(1).

22. Jegadeesh, N., \& Titman, S. (1993). Returns to buying winners and selling losers: Implications for stock market efficiency. Journal of Finance, 65-91.

23. (2001). Profitability of momentum strategies: An evaluation of alternative explanations. The Journal of Finance, 56, 699-720.

24. Le Sourd, V. (2011). Performance of socially responsible investment funds against an efficient SRI index: The impact. Nice: EDHEC Risk institute publication.

25. Lilti, J. J., \& Gouzerh, Y. (2007). Capital humain et CAPM conditionnel: une comparaison internationale des rentabilités d'actions. Banque et Marchés, 87, 14-24.

26. Lintner, J. (1965). The valuation of risk assets and the selection of risky investments in stock portfolios and capital budgets. The Review of Economics and Statistics, 47(1), 13-37.

27. L'Her, J. F., Masmoudi, T., \& Suret, J. M. (2004). Evidence to support the four-factor pricing model from the Canadian stock market. Journal of International Financial Markets, Institutions and Money, 14(4), 313328 .

28. Novethic. (2009), Islamic finance and SRI: any crossover? Retrieved from http://www.novethic.fr/novethic/upload/etudes/Note_Finance_Islamique.pdf

29. Saad, N. M., Majid, M. S. A., Kassim, S., Hamid, Z., \& Yusof, R. M. (2010). A comparative analysis of the performance of conventional and Islamic unit trust companies in Malaysia. International Journal of Managerial Finance, 6(1), 24-47.

30. Salaber, J. (2012). L'éthique et la gestion de portefeuille: comportement des investisseurs et rentabilité de l'investissement politiquement incorrect. (Thesis). University of Paris Dauphine.

31. Schröder, M. (2007). Is there a difference? The performance characteristics of SRI equity indexes. Journal of Business Finance and Accounting, 34, 331-348.

32. Sharpe, W. F. (1964). Capital asset prices: A theory of market equilibrium under conditions of risk. Journal of Finance, 19(3), 425-442. 


\section{Appendix 1: International Islamic Indices}

\begin{tabular}{|c|c|c|c|}
\hline Index & Launch & Provider & $\begin{array}{l}\text { Characteristics } \\
\end{array}$ \\
\hline $\begin{array}{l}\text { Dow Jones } \\
\text { Islamic Market } \\
\text { Index (DJIMI) }\end{array}$ & February 1999 & Dow Jones & $\begin{array}{l}\text { - } \text { Geographical coverage: } 66 \text { countries } \\
\text { - Sectorial allocation } \\
\text { - Shariah board: } 5 \text { independent Scholars } \\
\text { - trimestrial revision }\end{array}$ \\
\hline $\begin{array}{l}\text { Global Islamic } \\
\text { Index Series } \\
\text { (GIIS) }\end{array}$ & October 1999 & FTSE Group & 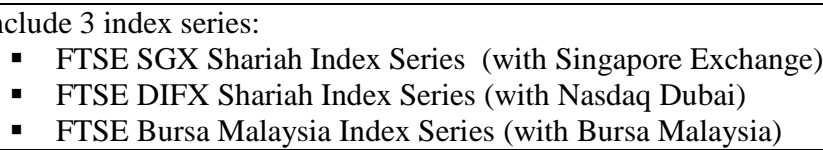 \\
\hline $\begin{array}{l}\text { MSCI Global } \\
\text { Islamic Indices }\end{array}$ & March 2007 & MSCI & $\begin{array}{l}\text { - Geographical coverage: } 70 \text { countries } \\
\text { - Sectorial allocation } \\
\text { - Shariah board: Dar al Istithmar ( } 5 \text { scholars }) \\
\text { - trimestrial revision }\end{array}$ \\
\hline $\begin{array}{l}\text { S\&P Shariah } \\
\text { Index Series }\end{array}$ & December 2006 & $\begin{array}{l}\text { Standard and } \\
\text { Poor's }\end{array}$ & $\begin{array}{l}\text { - } \text { Geographical coverage: } 70 \text { countries } \\
\text { - Sectorial allocation } \\
\text { - Shariah board: Rating Intelligence Partners } \\
\text { - } \quad \text { trimestrial revision }\end{array}$ \\
\hline $\begin{array}{l}\text { Stoxx Europe } \\
\text { Islamic indices }\end{array}$ & February 2011 & Stoxx & $\begin{array}{l}\text { - Geographical coverage: Europe and Euro Zone } \\
\text { - Sectorial allocation } \\
\text { - Shariah board: } 3 \text { independent Scholars } \\
\text { - trimestrial revision }\end{array}$ \\
\hline
\end{tabular}




\section{Appendix 2: Quantitative and Qualitative Screens to Filter out Dow Jones Islamic Market Index}

According to DJIMI standards, if the company has lines of business in any one of the following sectors defined by the Industry Classification Benchmark (ICB), it is considered inappropriate for Islamic investment purposes and is excluded from the index:

- 2717 Defence

- 3535 Distillers and Vintners

- 3577 Food Products

- 3745 Recreational Products

- 3785 Tobacco

- $\quad 5337$ Food Retailers \& Wholesalers

- 5553 Broadcasting and Entertainment
- 5555 Media Agencies

- 5752 Gambling

- 5753 Hotels

- 5755 Recreational Services

- 5757 Restaurants and Bars

- 8355 Banks

- 8532 Full Line Insurance

- 8534 Insurance Brokers
- 8536 Property and Casualty Insurance

- 8733 Real Estate Holding and Development

- 8773 Consumer Finance

- 8775 Specialty Finance

- 8777 Investment Services

- 8779 Mortgage Finance

The screens are designed to exclude companies with financial ratios incompatible with Shariah investment guidelines. Thus, to be included in Dow Jones Islamic Market Index, all of the following should be less than 33\%:

- $\quad$ Total debt divided by trailing 24-month average market capitalization

- $\quad$ The sum of a company's cash and interest-bearing securities divided by trailing 24 month average market capitalization

- $\quad$ Accounts receivables divided by trailing 24-month average market capitalization. 


\section{NOTES}

